\title{
Phytochemical Properties of Seeds and Oils of Cassia Fistula (Two Locations)
}

\author{
MUKHAN WATI*, SHEETAL and M. KHABIRUDDIN \\ Department of Chemistry and Biochemistry Chaudhary Charan Singh Haryana \\ Agricultural University Hisar - 125004, Haryana, India. \\ *Corresponding author E-mail: mukhandagar88@gmail.com \\ http://dx.doi.org/10.13005/ojc/330443
}

(Received: February 23, 2017; Accepted: June 12, 2017)

\begin{abstract}
In the present study the crude oil and defatted seed cake were analyzed to calculate phenolics, flavonoid, totaltocopherol and DPPH activity for two locations. The $C$. fistula had highest phenolics $12.0 \pm 0.0 \mathrm{mgGAE} / \mathrm{g}$, flavonoids content $2.9 \pm 0.0 \mathrm{mgCAE} / \mathrm{g}$, total tocopherol $185.6 \mathrm{mg} / \mathrm{g}$ and carotenoids was $131.0 \mathrm{mg} / \mathrm{kg}$. The maximum antioxidant activity was $83 \%$ and in terms of $\mathrm{IC}_{50}$ value was $0.041 \pm 0.0 \mathrm{mg} / \mathrm{ml}$. The fatty acids profile shown that the significant amount of fatty acids were linoleic and oleic acid.
\end{abstract}

Keywords: C. fistula, total phenolics, antioxidant activity, minerals, fatty acid composition.

\section{INTRODUCTION}

Amaltash (C. fistula) conjointly called as Indian laburnum, was a plant of Leguminoceae family. The plant may be a moderate sized deciduous tree, distributed throughout Asian nation and is rumored to be aperient, astringent, laxative, purgative and medicine, Indian laburnum may be a folks remedy for burns, constipation, convulsions, delirium, epilepsy, hematuria, diarrhea, pimples and gravel ${ }^{1}$. Species of Cassia are rich sources of flavonoids, anthraquinones and polysaccharides. The flavonol and xanthone glycosides have been reported from the bark of the plant. A stem bark powered contained tannins, lupeol, hexacosanol, $\beta$-sitosterol. The pulp contains significant amount of protein, carbohydrate, arginine, leucine, and glutamic acid. Pods contain fistulic acid, sugar, astringent matter, gluten, matter; Seed contain vernolic oil, sterculic and malvalic acids.

\section{MATERIALS AND METHODS}

Dry pods of $C$. fistula were collected from field area of CCS HAU, Hisar and district Palwal, Haryana, India. The seeds were expelled from their pods and ground to powder form utilizing electric granulating machine. The powdered seed was utilized for analysis. 


\section{Chemicals}

The chemicals utilized for the analyses were from Ranbaxy Merk and Qualigens, of most elevated immaculateness. Oil substance will be determined by Soxhlet strategy utilizing petroleum ether $\left(60-80^{\circ} \mathrm{C}\right)$ for $8 \mathrm{~h}$. The compound attributes of seed oil will be resolved by $\mathrm{AOAC}^{2}$ standard method.

\section{Mineral contents \\ Reagents \\ Diacid mixture}

Nitric acid and perchloric acid was mixed in ratio 5:1 just before use.

\section{Hydrochloric mixture (1\%)}

$1 \mathrm{ml}$ of conc. $\mathrm{HCl}$ was added in $50 \mathrm{ml}$ water and a 100 $\mathrm{ml}$ total volume made with water as distilled.

\section{Method}

Two gram powdered sample of the seeds was digested with $15 \mathrm{ml}$ of diacid mixture $\left(5 \mathrm{HNO}_{3}: \mathrm{HClO}_{4}\right)$ in a conical flask by heating on hot plate in open space till clear white precipitates settle down at bottom of conical flask. The precipitates were dissolved in $1 \% \mathrm{HCl}$ prepared in double distilled water, filtered and final volume of filterate used as $50 \mathrm{ml}$ with water as double distilled and determined by AAS.

\section{Fatty acid spectrum}

Preparation of methyl esters

Methyl esters were prepared by the method ${ }^{3}$ as described below

\section{Reagents}

(a) Sodium methoxide $(0.5 \mathrm{~N})$

(b) Carbon disulphide

(c) Activated charcoal

\section{Method}

A suitable amount of oil sample was taken in a test tube and $0.50 \mathrm{ml}$ of $0.50 \mathrm{~N}$ sodium methoxide was added and covered with aluminium foil and then immersed in a water bath at $65^{\circ} \mathrm{C}$ to a depth of half inch and was shaken vigorously for 2 - $3 \mathrm{~min}$. The mixture became homogenous indicating the complete esterification of the oil sample. The test tube was removed from the water bath and cooled to room temperature. One $\mathrm{ml}$ of carbon disulphide was added and shaken for 1 - 2 min. Separated the lower layer and approximately $100 \mathrm{mg}$ of activated charcoal was added mixed uniformly and filtered. The filtrate constituted all methyl esters of fatty acids.

\section{Fractination of methyl esters by GLC}

Methyl esters of unsaturated fats were isolated utilizing Chemito 8610 HT Gas chromatograph furnished with FID and a BPX70, $0.25 \mathrm{ml}$ melded silica segment (SGE Pvt. Ltd., Ringwood, Victoria, Australia) was utilized. The transporter gas was hydrogen and infusion was worked in the part mode, the split proportion being around 50:1. Injector and locator temperature were $270^{\circ} \mathrm{C}$ and $280^{\circ} \mathrm{C}$ separately. The temperature of oven was held at $70^{\circ} \mathrm{C}$ for $1 \mathrm{~min}$. and after that customized at $30^{\circ} \mathrm{C} / \mathrm{min}$. to $170^{\circ} \mathrm{C}$ took after by further programming at $30^{\circ} \mathrm{C} / \mathrm{min}$. to $200^{\circ} \mathrm{Cx}$ and held at this temperature for 6 min. Information was caught and dissected with, Chemito 5000 integrator (Tashniwal Instruments, India Ltd.).

\section{Phenolics content}

The phenolics were calculated by a reagent named as Folin-Ciocalteu. ${ }^{4}$

\section{Principle}

All phenolic mixes exhibit in the plant concentrates are oxidized by Folin-Ciocalteu reagent. This reagent is a blend of phosphotungstic corrosive and phosphomolybdic corrosive which, after oxidation of the phenols, is lessened to a blend of blue oxides of tungsten and molybdenum. The blue colorcreated has a maximum absorption at $730 \mathrm{~nm}$, and is specifically relative to the amount of phenolics present.

\section{Reagent \\ Gallic acid \\ Methanol \\ Sodium carbonate $(20 \% \mathrm{w} / \mathrm{v})$}

\section{Phenolics in seed oil and methanol extracts of defatted seed cake}

The phenolics in seed oil and methanol extracts of defatted seed cake of $C$. fistula, added one $\mathrm{ml}$ of one $\mathrm{mol} / \mathrm{L}$ reagent of Folin-Ciocalteu and two $\mathrm{ml}$ of $\mathrm{Na}_{2} \mathrm{CO}_{3}(20 \% \mathrm{w} / \mathrm{v})$ to the $1.0 \mathrm{ml}$ extract blended and a total volume of $10 \mathrm{ml}$ made with water. Following 30 minutes, the blend was centrifuged at $6000 \mathrm{rpm}$ for 10 minutes. At that point 
the absorbance of supernatant arrangement was measured at $730 \mathrm{~nm}$ utilizing Spectronic 20 (Milton Roy Company) spectrophotometer against a blank arranged comparably with a similar dissolvable however precluding the concentrate. The measure of aggregate phenolics introduce in the concentrates was computed from the standard curve and the results are expressed as milligrams of gallic acid equivalent per gram (mg GAE/g).

\section{Determination of flavonoids}

The colorimetric assay, as described ${ }^{5}$ used for flavonoids determination.

\section{Principle}

The fundamental standard of aluminum chloride colorimetric measure is that aluminum chloride formed acid stable compounds with the C-4 keto assemble and either the C-3 or C-5 hydroxyl gathering of the flavones and flavonols. Furthermore, it additionally formed acid labile compounds with the o-dihydroxyl assembles in the A or B rings of flavonoids.

\section{Reagents}

Catech in

$5 \% \mathrm{NaNO}_{2}$ $10 \% \mathrm{AlCl}_{3}$ $1 \mathrm{M} \mathrm{NaOH}$

\section{Estimation of flavonoids in seed oil and methanol extracts of defatted seed cake}

One $\mathrm{ml}$ of diluted concentrate was added to test tubes containing $4 \mathrm{ml}$ of distilled water. To the mixture was included $0.3 \mathrm{ml} 5 \% \mathrm{NaNO}_{2}$. Following 5 minute, $0.3 \mathrm{ml} \mathrm{10 \%} \mathrm{AlCl}_{3}$ was included. Quickly, $2.0 \mathrm{ml} 1 \mathrm{M} \mathrm{NaOH}$ was included and the aggregate volume was made upto $10.0 \mathrm{ml}$ with water. The arrangement was blended altogether and the absorbance of both the specimens and blank was perused at $510 \mathrm{~nm}$ utilizing UV spectrophotometer Model Spectronic 20 (Milton Roy Company). Add up to flavonoids of tests were communicated as mg catech in equivalent per gram (mg CAE/g).

\section{Total Tocopherol}

Aliquots (10, 15, 20, 25,30,35 and 40 ppm of an answer of $\mu$ tcopherol in the ethanol were exchanged to a volumetric flask and the volume was changed in accordance with $8 \mathrm{ml}$ with ethanol. Each of the arrangement and $1.0 \mathrm{ml}$ of 2, 2/ - dipyridyl reagent were pipetted into $10.0 \mathrm{ml}$ volumetric flask and blended. A $1.0 \mathrm{ml}$ part of ferric chloride reagent was added to the $10.0 \mathrm{ml}$ volumetric flask and the mixture shaken for 10 seconds. The absorbance of the blend was perused at $520 \mathrm{~nm}$ against ethanol as a blank ${ }^{6}$. Then the standard curve was drawn. The above portrayed methodology was trailed by utilizing 10, 20, 30, 40 mg test arrangements. The"-tocopherol in the extract was calculated by regression equation of the standard curve. $200 \pm 10 \mathrm{mg}$ of the oil test were weighed precisely into a $10.0 \mathrm{ml}$ volumetric flagon. $5.0 \mathrm{ml}$ of toluene were included by pipette and the oil taken into arrangement. $3.5 \mathrm{ml}$ of 2, 2' - bipyridine $(0.07 \% \mathrm{w} / \mathrm{v}$ in $95 \%$ watery ethanol) and $0.5 \mathrm{ml}$ of ferric chloride $(0.2 \% \mathrm{w} / \mathrm{v}$ in $95 \%$ fluid ethanol) were included that in that order. The arrangements were made up to $10.0 \mathrm{ml}$ with $95 \%$ fluid ethanol. In the wake of remaining for one min. the ingestion at 520 $\mathrm{nm}$ was resolved utilizing as a kind of perspective a blank arrangement, arranged as above however excluding the oil.

\section{Carotenoids}

Determination of total carotenoids was done by the method. ${ }^{7}$

\section{Reagent: Cyclohexane Method}

Oil $(2.0 \mathrm{~g})$ was taken in $100 \mathrm{ml}$ conical flask. The oil was dissolved in cyclohexane $(2.5 \% \mathrm{w} / \mathrm{v})$ and the absorbance was perused at $417 \mathrm{~nm}$ and afterthat carotenoids was determined by using the equation given below

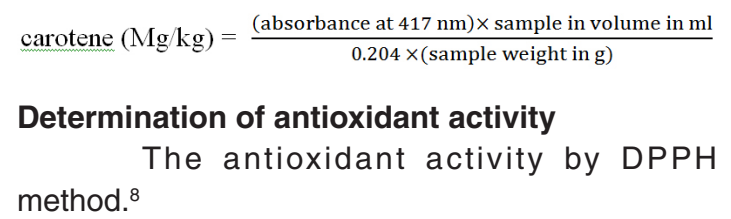

\section{Principle}

(DPPH) is a steady free radical that demonstrates a most extreme retention at $517 \mathrm{~nm}$. Cancer prevention agents respond with DPPH and change over it to $\alpha, \alpha$-diphenyl, $\beta$-picryl hydrazine, which includes shading staining of a violet that is measured at $517 \mathrm{~nm}$. The level of staining shows the searching capability of the cancer prevention agent extricate. At the point when DPPH experiences 
proton giving substance, for example, cancer prevention agent and a radical animal categories, the absorbance at $517 \mathrm{~nm}$ vanishes on the grounds that the DPPH radical is searched.

\section{Reagents}

DPPH: $0.025 \mathrm{gL}^{-1}$ in $50 \%$ methanol

\section{Method}

Briefly $0.01,0.02,0.03,0.04$, 0.05,0.06,0.07,0.08,0.09 mg methanol extracts of oil and defatted seed cake were added to one $\mathrm{ml}$ of diphenyl- picrylhydrazyl radical $\left(0.025 \mathrm{gL}^{-1}\right.$ in methyl alcohol), final volume was made to $10 \mathrm{ml}$ with methyl alcohol and mixed. Absorbance was measured at $517 \mathrm{~nm}$ till a steady state is reached using the spectrophotometer Spectronic 20 (Milton Roy Company). Similarly, a control sample was also prepared. For each sample, three replicate were carried out. Here, butylatedhydroxylanisole (BHA) with conc. 0.01-0.09 $\mathrm{mg} / \mathrm{ml}$ were used as standard similarly. Then using a quadratic regression equation $\left(y=a x^{2}+b x+c\right)$ was obtained. By putting $y=50 \%$ in the equation $\mathrm{IC}_{50}$ was calculated by using the formula:

$X=\frac{-b \pm \sqrt{b^{2}-4 a c}}{2 a}$

Where, $x=I C_{50}(\mathrm{mg} / \mathrm{ml})$

\section{Calculation}

$$
\% \mathrm{DPPH}_{\text {sc }}=\left\{\left(\mathrm{A}_{\text {cont }}-\mathrm{A}_{\text {samp }}\right) / \mathrm{A}_{\text {cont }}\right\} \times 100
$$

Where $\mathrm{A}_{\text {cont }}$ is the absorbance of control and $A_{\text {samp }}$ is the absorbance of sample.

A graph was drawn by using \% DPPH (y-axis) against extract concentration (x-axis).

\section{Data analysis}

The results were determined as mean of three replicates \pm standard deviation by Online Statiscal Analysis (OPSTAT www.hau.ernet.in).

\section{RESULTS AND DISCUSSIONS}

\section{Mineral Composition of seeds}

Minerals are required to initiate many enzymic responses inside the body. Life is needy upon the body's capacity to keep up harmony between the minerals ${ }^{9}$. The mineral contained in these seeds contemplated may assume imperative part in sustenance. Magnesium, calcium and potassium in the human were required for building red platelet and for body instrument ${ }^{10}$. The seeds of $C$. fistula (Palwal and Hisar) contained critical measure of vital minerals as Calcium maximum $729.7 \pm 1.5 \mathrm{mg} / 100 \mathrm{~g}$, potassium $830.6 \pm 3.7$ $\mathrm{mg} / 100 \mathrm{~g}$, sodium $109.6 \pm 1.6 \mathrm{mg} / \mathrm{kg}$ remaining are in lower concentration. Our results was similar as obtained $^{11}$. Calcium assumes a noteworthy part in CNS work. Calcium is fundamental for nerve motivation conduction and enacts a few compounds which create neurotransmitters. Phosphorus is fixing to calcium in bone structure and assumes a critical part in CNS work. Numerous proteins contain as a base phospho proteins. Phospholipids are included in nerve conduction. Phosphate is the essential particle in additional and intracellular liquid. It helps absortion of dietary constituents, keep up the blood at a somewhat antacid levels, directs protein action and is included in the transmission of nerve driving forces.

\section{Fatty acid composition}

For fatty acids composition first converted into their respective volatile esters by transesterification, i.e. by converting them from glycerol esters to methyl esters. The esters are then identified and quantified by injecting the processed samples into GLC and by comparing with chromatographic patterns of a set of standard esters. The important major fatty acid in $C$. fistula two locations (Palwal \& Hisar) was maximum linoleic acid $54.3 \pm 0.7 \%$, oleic acid $19.2 \pm 0.4 \%$ and Palmitic acid $18.5 \pm 0.3 \%$. It was also shown by the results that fatty acids obtained from two locations were different.

\section{Carotenoids content}

The oils color is mainly by carotenoid. Carotenoids protect cells by the damage of light, air and sensitiser having the ability to inhibit singlet oxygen and act as a natural antioxidants other than photosensitization ${ }^{12}$. Carotenoid value determined in oils of the seeds studied in Palwal and Hisar locations were $131.0 \pm 0.2$ and $112.6 \pm 2.0 \mathrm{mg} / \mathrm{kg}$. Carotenoids is a type of antioxidant, higher value of this indicates higher antioxidant activity. 


\section{Total Phenolics Content}

Plant phenolics are optional metabolites which are naturally aromatic and are highly antioxidants in view of their capacity to inhibits the free radicals and active oxygen. Really phenolics show significant free radical-inhibition activity. In this way, the measure of aggregate phenolics in two areas (Palwal and Hisar) of $C$. fistula were determined.

Our findings showed that the substance of aggregate phenolics of C.fistula of two areas were highest in the methanol extract of defatted seed cake

Table 1: Mineral Composition of seeds of $C$. fistula

\begin{tabular}{lll}
\hline Parameters & \multicolumn{2}{c}{ Composition } \\
\hline & Palwal & Hisar \\
\cline { 2 - 3 } $\mathrm{Ca}(\mathrm{mg} / 100 \mathrm{~g})$ & $720.4 \pm 1.8$ & $729.7 \pm 1.5$ \\
$\mathrm{~K}(\mathrm{mg} / 100 \mathrm{~g})$ & $830.6 \pm 3.7$ & $820.5 \pm 2.4$ \\
$\mathrm{Na}(\mathrm{mg} / 100 \mathrm{~g})$ & $109.6 \pm 1.6$ & $100.4 \pm 1.3$ \\
$\mathrm{Mg}(\mathrm{mg} / 100 \mathrm{~g})$ & $7.8 \pm 0.5$ & $8.7 \pm 0.1$ \\
$\mathrm{Fe}(\mathrm{mg} / 100 \mathrm{~g})$ & $167.0 \pm 0.8$ & $170.0 \pm 0.3$ \\
$\mathrm{Zn}(\mathrm{mg} / 100 \mathrm{~g})$ & $2.4 \pm 0.4$ & $2.0 \pm 0.2$ \\
$\mathrm{Co}(\mathrm{mg} / 100 \mathrm{~g})$ & $0.1 \pm 0.0$ & $0.1 \pm 0.1$ \\
$\mathrm{Mn}(\mathrm{mg} / 100 \mathrm{~g})$ & $0.2 \pm 0.1$ & $0.3 \pm 0.2$ \\
$\mathrm{Cu}(\mathrm{mg} / 100 \mathrm{~g})$ & Traces & Traces \\
$\mathrm{P}(\mathrm{mg} / 100 \mathrm{~g})$ & $12.0 \pm 0.3$ & $10.4 \pm 0.2$ \\
\hline
\end{tabular}

Values are mean of three replicates \pm standard error

Table 2: Profile of fatty acids in seed oil of $C$. fistula

\begin{tabular}{lll}
\hline Parameters & \multicolumn{2}{c}{ Composition } \\
\hline & Palwal & Hisar \\
\cline { 2 - 3 } Palmitic acid $\left(C_{16: 0}\right)$ & $18.5 \pm 0.3$ & $18.3 \pm 0.4$ \\
Stearic acid $\left(C_{18: 0}\right)$ & $0.7 \pm 0.0$ & $1.3 \pm 0.2$ \\
Oleic acid $\left(C_{18: 1}\right)$ & $19.2 \pm 0.4$ & $18.9 \pm 0.4$ \\
Linoleic acid $\left(C_{18: 2}\right)$ & $54.3 \pm 0.7$ & $53.6 \pm 0.7$ \\
Linolenic acid $\left(C_{18: 3}\right)$ & $1.0 \pm 0.1$ & $1.1 \pm 0.3$ \\
Arachidic acid $\left(C_{20: 0}\right)$ & $0.3 \pm 0.1$ & $0.1 \pm 0.1$ \\
Eicosenoic acid $\left(C_{20: 1}\right)$ & $2.4 \pm 0.4$ & $2.3 \pm 0.2$ \\
Behanic acid $\left(C_{22: 0}\right)$ & $0.2 \pm 0.0$ & $0.3 \pm 0.1$ \\
\hline
\end{tabular}

Values are mean of three replicates \pm standard error
$12.0 \pm 0.0 \mathrm{mg} \mathrm{GAE} / \mathrm{g}$ as compared to phenolic extract of seed oil $7.0 \pm 0.3 \mathrm{mg} \mathrm{GAE} / \mathrm{g}$.

\section{Flavonoids Content}

Flavonoids are presumably the most essential class of characteristic phenolics and can give electrons or hydrogen molecules promptly, so they can directly rummage responsive oxygen species. They are additionally antioxidants referred to go about as radical scavenger and as metal chelators. Along these lines, the flavonoids of $C$. fistula (two locations) were resolved. The TFCs are communicated as far as catech in equivalent (CE).

The flavonoids content highest in methanolic extract of defatted seed cake were $(2.9 \pm 0.0 \mathrm{mg}$ $\mathrm{CAE} / \mathrm{g}$ to $2.1 \pm 0.2 \mathrm{mg} \mathrm{CAE} / \mathrm{g}$ ) in comparison to seed oil $1.3 \pm 0.1$ and $1.1 \pm .0 .3 \mathrm{mg} \mathrm{CAE} / \mathrm{g}$.

\section{Total Tocopherol}

Tocopherols are characteristic antioxidant, which are available in every vegetable oil in various sums that assume a key part in saving oil from rancidity amid capacity in this manner delaying its time span of usability. Tocopherols go about as natural criminals of free radicals and could counteract infections, other than having an imperative nutritious capacity for people as a wellspring of Vitamin $E^{13,14}$. The tocopherol substance of nourishments is critical to ensure sustenance lipids against autoxidation and, in this way to build their capacity life and their esteem as wholesome nourishments. The tocopherol content in the phenolic extracts of seed oil of $C$. fistula two areas (Palwal and Hisar) were $8.4 \pm 0.1 \mathrm{mg} / \mathrm{g}$ to $10.2 \pm 0.3 \mathrm{mg} / \mathrm{g}$ and in methanolic extracts of defatted seed cake were $176.3 \pm 0.2 \mathrm{mg} / \mathrm{g}$ to $185.6 \pm 0.5 \mathrm{mg} / \mathrm{g}$. In comparision of total tocopherol in unrefined oil and methanol extracts of defatted seed cake, we found that there were large difference of aggregate tocopherol content between seed oil and seed cake.

\section{DPPH free radical scavenging activity}

$(\mathrm{DPPH} \bullet)$ is one of only a handful stable natural free radical, regularly utilized as a part of assessment of radical scavenging movement of natural and manmade antioxidants complexes, plant extracts and foods ${ }^{15,16}$. Alcoholic arrangements of DPPH radical have a trademark absorption maximum at $517 \mathrm{~nm}$. 
Table 3: Phytochemical components and antioxidant activity in phenolic extract of seed oil and methanolic extract of defatted seed cake of $\boldsymbol{C}$. fistula

\begin{tabular}{|c|c|c|c|c|}
\hline \multirow[t]{3}{*}{ C. fistula } & \multicolumn{4}{|c|}{ Composition } \\
\hline & \multicolumn{2}{|c|}{ Phenolic extract of seed oil } & \multicolumn{2}{|c|}{$\begin{array}{l}\text { methanolic extract of } \\
\text { defatted seed cake }\end{array}$} \\
\hline & Palwal & Hisar & Palwal & Hisar \\
\hline Total phenolics(mgGAE/g) & $7.0 \pm 0.0$ & $11.5 \pm 0.6$ & $10.3 \pm 0.1$ & $12.0 \pm 0.0$ \\
\hline Flavonoids (mgCAE/g) & $1.3 \pm 0.1$ & $1.1 \pm 0.3$ & $2.9 \pm 0.0$ & $2.1 \pm 0.2$ \\
\hline Total tocopherol(mg/g) & $8.4 \pm 0.1$ & $10.2 \pm 0.3$ & $176.3 \pm 0.2$ & $185.6 \pm 0.5$ \\
\hline Carotenoid content $(\mathrm{mg} / \mathrm{kg})$ & $131.0 \pm 0.2$ & $112.6 \pm 2.0$ & - & - \\
\hline DPPH IC ${ }_{50}(\mathrm{mg} / \mathrm{ml})$ & $0.040 \pm 0.0$ & $0.041 \pm 0.0$ & $0.028 \pm 0.0$ & $0.033 \pm 0.0$ \\
\hline Antioxidant activity (\%) & 65 & 62 & 83 & 71 \\
\hline
\end{tabular}

Values are mean of three replicates \pm standard error

All the phenolic concentrates were screened with the expectation of complimentary radical rummaging action against $\mathrm{DPPH}$. The maximum antioxidant capacity of $C$. fistula in seed oil were from $62 \%$ to $65 \%$ and in seed cake from $71 \%$ to $83 \%$ at a concentration of $0.06 \mathrm{mg} / \mathrm{ml}$ which is higher in methanol extract of defatted seed cake. But earlier result showed the antioxidant activity of methanolic bark extract of $C$. fistula was $58.19 \%{ }^{17}$.

The antioxidant activity in terms of $\left(\mathrm{IC}_{50}\right)$ displayed by phenolic extract of seed oil of $C$. fistula of two locations were $0.040 \pm 0.0 \mathrm{mg} / \mathrm{ml}$ to $0.041 \pm 0.0$ $\mathrm{mg} / \mathrm{ml}$ and in methanolic extracts were $0.028 \pm 0.0$ $\mathrm{mg} / \mathrm{ml}$ to $0.033 \pm 0.0 \mathrm{mg} / \mathrm{ml}$. Our perception in both the locations higher in seed oil as compared to seed cake. Our result showed that the antioxidant activity higher in seed extracts as compared to leaves shown earlier ${ }^{18}$. Higher polyphenolic content compares with higher cell reinforcement action which may be because of the joined activity of present substances in factor fixations and their hydrogen iota giving capacities. In any case, the higher extremity dissolvable portions were not the most dynamic as the radical searching action of a specific cell reinforcement relies on upon structure and in addition on the kind of response kinetics.

\section{ACKNOWLEDGMENT}

We are thankful to the University of CCS HAU, Hisar (India) and Dr. M. Khabiruddin for continued support of our work.

In this study the phytochemicals were found in significant amount. The overall phenolics and antioxidant activity are higher in methanolic extracts as compared to phenolic extracts of seed oil. Thus it is concluded that this plant is a good source of natural antioxidant and further used as a good supplement for food and feed purpose.

\section{REFERENCES}

1. Duke, J. A. and Wain, K. K. Medicinal plants of the world. Computer index with more than 85,000 entries. 1981,3 .

2. AOAC. Official methods of analyses. Association of Official Analytical Chemists: Washington, DC. 1990.

3. Luddy, F. E.; Breadford, R. A.; Herb, S. F. and Paul, M. A rapid quantitative procedure for the preparation of methyl esters of butter, fat and other fat. J. of the Am. Oil Chem.' Soc. 1968, 45, 549-552.

4. Singleton, V.L.and Rossi, J.A.Colorimetry of total phenolics with phophomolybdicphophotungstic acid reagents. Am. J. Enology Viticulture.1965, 16, 144-158.

5. Zhishen, J.; Mengcheng, T. and Jjianming, 
W. Determination of flavonoid contents in mulberry and their scavenging effects on superoxide radicals. Food Chemistry. 1999, 64,555- 559.

6. Philip, B.; Bernard, L. and William, H. Vitamins and Deficiency Diseases, In: Practical Physiological Chemistry, Mc Graw- Hill company, INC. New York, Toronto, London, 1954, 1272-1274.

7. Vasconcellous, J. A., Berry, J.W. and Weber, C.W. The properties of Cucurbitafoetidissima seed oil. J. Am. Oil Chem. Soc.1980, 57, 310313.

8. Hatano, T.; Kagawa, H.; Yasahara, T. and Okuda, T. Two new flavonoids and other constituents in licorice root. Their relative astringency and radical scavenging effects. Chem. Pharma. Bull.1988, 36, 2090-2097.

9. Watts, D. L. Trace Elements and Other Nutrients: Clinical Application of Tissue Mineral Analysis. $2^{\text {nd }} E d n ;$ Trace Elements, USA; ISBN-13. 1997, 182.

10. WHO. Trace Elements in Human Nutrition and Health. World Health Organisation, Geneva, Switzerland, ISBN- 13. 1996, 343.

11. Akinyede, A. I. andAmoo I. A. Chemical and Functional Properties of Full Fat and Defatted Cassia fistula Seed Flours. Pakistan Journal of Nutrition. 2009, 8 (6): 765-769.

12. Krinsky, N. Antioxidant functions of carotenoids. Free Radical Biology and
Medicine. 1989, 7, 617-635.

13. Monahan, F. J.; Gray, J. I.; Asghar, A.; Haug, A.; Shi, B. and Bukley, D. J. Effect of dietary lipid and Vitamin E supplementation on free radical production and lipid oxidation in porcine muscle microsomal fractions. Food Chem. 1993, 46, 1-6.

14. Brigelius-Flohe, R.; Kelly, F. J.; Salonem, J. T.; Neuzil, J.; Zingg, J. M. and Azzi, A. The European perspective on vitamin $\mathrm{E}$ : current knowledge and future research. Am. J. Clin. Nutr. 2002, 76, 703-716.

15. Brand-Williams, W.; Cuvelier M. E. and Berset, C. Use of a free radical method to evaluate antioxidant activity. Lebensm. Wiss. Technol,1995, 28: 25-30.

16. Yen G. C. and Duh P. D. Scavenging effect of methanolic extracts of peanut hulls on freeradical and active-oxygen species. J. Agric. Food. Chem., 1994, 42, 629-632.

17. Noorhajati, H.; Tanjung, M.; Aminah, N. S. and Suwandi, J. S. A. Antioxidant Activities of Extracts of Trengguli Stem Bark (Cassia fistula L.). International Journal of Basic \& Applied Sciences.2012, 12 (4): 85-89.

18. Jose, B. and Reddy, L. J. Evaluation of Antibacterial and DPPH Radical Scavenging Activities of the Leaf Extracts of Cassia fistula Linn from South India. Open Access Scientific Reports. 2013, 2(8): 2-4. 